\title{
A New Species of Amolops from Thailand (Amphibia, Anura, Ranidae)
}

\author{
Masafumi Matsui $^{1 *}$ and Jarujin Nabhitabhata ${ }^{2}$ \\ ${ }^{1}$ Graduate School of Human and Environmental Studies, Kyoto University, \\ Sakyo-ku, Kyoto 606-8501, Japan \\ ${ }^{2}$ National Science Museum, Technopolis, Klong 5, Klongluang District, \\ Pathun thani 12120, Thailand
}

\begin{abstract}
We describe a new species of torrent-dwelling ranid frog of the genus Amolops from western to peninsular Thailand. Amolops panhai, new species, differs from its congeners by the combination of: small body, males $31-34 \mathrm{~mm}$, females $48-58 \mathrm{~mm}$ in snout-vent length; head narrower than long; tympanum distinct; vomerine teeth in short, oblique patches; first finger subequal to second; disc of first finger smaller than that of second, with circummarginal groove; no wide fringe of skin on third finger; toes fully webbed; outer metatarsal tubercle present; supratympanic fold present; dorsolateral fold indistinct; axillary gland present; horny spines on back, side of head and body, and chest absent; large tubercles on side of anus absent; glandular fold on ventral surface of tarsus absent; nuptial pad and paired gular pouches present in male; white band along the upper jaw extending to shoulder absent; larval dental formula 7(4-7)/3(1). This new species is the second anuran discovered which has a disjunct distribution around the Isthmus of Kra.
\end{abstract}

Key words: Amolops, new species, Southeast Asia, tadpole, taxonomy, zoogeography

\section{INTRODUCTION}

Oriental ranid frogs related to Amolops Cope, 1865 (sensu lato) are characterized by their peculiar larvae, which inhabit mountain torrents using an abdominal, suctorial disk (Inger, 1966). After Inger (1966) confirmed this genus as valid, Yang (1991) split it into the genera Amolops (sensu stricto), Huia, and Meristogenys. In contrast, Dubois (1992) relegated Yang's (1991) three genera to subgenera of the genus Amolops (sensu lato) and added the subgenus Amo. Currently, Yang's (1991) classification is more popular (e.g., Frost, 2004), but Matsui et al. (2006) recently evaluated these two different taxonomic systems. Through analyses of mitochondrial cyt-b gene sequences, Matsui et al. (2006) confirmed the monophyly of Meristogenys and the invalidity of Amo, although they did not show monophyly for either Amolops (sensu stricto) or Huia.

Two species assigned to Amolops (sensu stricto) have previously been recorded from Thailand (Taylor, 1962): $A$. marmoratus (Blyth, 1855) from the northernmost area [Chiang Mai; as Staurois afghanus (Günther, 1858)] and $A$. larutensis (Boulenger, 1899) from disjunct areas of the southern (Pattani and Yala) and northern (Chumphon) peninsular regions (as $S$. larutensis). During our faunal surveys of Thailand between 1995 and 1997, we collected larval and adult specimens of an apparently undescribed species of this genus from the western (Kanchanaburi) and the northern and central peninsular regions (Prachuap Khiri Khan and

\footnotetext{
${ }^{*}$ Corresponding author. Phone: +81-75-753-6846;

Fax : +81-75-753-6846;

E-mail : fumi@zoo.zool.kyoto-u.ac.jp
}

Ranong), which we describe below as a new species.

\section{MATERIALS AND METHODS}

A field survey was conducted in western and peninsular Thailand between December 1995 and January 1997. In the field, we recorded calls using a cassette tape recorder (Sony TC-D5) with an external microphone (Sony ECM-23). After collecting specimens, we took tissues for later biochemical analysis, and fixed them as vouchers. Metamorphosed specimens were fixed in 10\% formalin and later preserved in $70 \%$ ethanol. Larvae were fixed and preserved in $5 \%$ formalin. Assignment of larvae to the new species was based upon the occurrence of adults of that species where the larvae were collected.

For preserved metamorphosed specimens, we took the following 18 body measurements (Table 1), mainly following Matsui (1984), to the nearest $0.1 \mathrm{~mm}$ with dial calipers under a binocular dissecting microscope: snout-vent length (SVL); head length (HL) from tip of snout to hind border of the angle of jaw (not measured parallel with the median line); snout length (SL); eye length (EL); tympanum-eye distance (T-EL); tympanum diameter (TD); head width (HW); internarial distance (IND); interorbital distance (IOD); upper eyelid width (UEW); forelimb length (FLL); third finger disk diameter (3FDW); fourth toe disk diameter (4TDW); hindlimb length $(\mathrm{HLL})$; tibia length ( $\mathrm{TL})$; foot length $(\mathrm{FL})$ from proximal end of inner metatarsal tubercle to tip of fourth toe; first toe length (1TL) from distal end of inner metatarsal tubercle to tip of first toe; inner metatarsal tubercle length (IMTL).

For larvae, the following 17 measurements to the nearest 0.01 $\mathrm{mm}$ were taken using a binocular dissecting microscope equipped with a micrometer: total length (TOTL); head-body length (HBL); maximum head-body width (HBW); body depth; eye-snout distance; eyeball diameter; internarial distance; interorbital distance; oral disk width; abdominal disk length; abdominal disk width; spiracle length; tail length; maximum tail depth; maximum tail muscle depth; maximum dorsal fin depth; maximum ventral fin depth. Measurements 
Table 1. Measurements of 18 characters in Amolops panhai. SVL ( $\bar{x} \pm 1 S D$, in $\mathrm{mm})$ and medians of ratios $(\mathrm{R})$ of other characters to $S V L$, followed by ranges in parenthesis. See text for character abbreviations.

\begin{tabular}{|c|c|c|c|c|c|c|c|}
\hline Locality & Sex & $S V L \pm S D$ & $\mathrm{RHL}$ & RSL & REL & RT-EL & RTD \\
\hline Phetchaburi and Kanchanaburi & $\begin{array}{l}\text { Males } \\
(\mathrm{N}=7)\end{array}$ & $\begin{array}{c}32.6 \pm 0.83 \\
(31.7-33.9)\end{array}$ & $\begin{array}{c}40.3 \\
(39.4-41.8)\end{array}$ & $\begin{array}{c}16.2 \\
(15.6-17.0)\end{array}$ & $\begin{array}{c}18.1 \\
(17.3-19.6)\end{array}$ & $\begin{array}{c}2.7 \\
(1.3-3.9)\end{array}$ & $\begin{array}{c}8.2 \\
(7.6-9.1)\end{array}$ \\
\hline Phetchaburi & $\begin{array}{c}\text { Females } \\
(\mathrm{N}=10)\end{array}$ & $\begin{array}{c}53.9 \pm 3.62 \\
(47.2-57.5)\end{array}$ & $\begin{array}{c}37.2 \\
(36.6-39.2)\end{array}$ & $\begin{array}{c}15.5 \\
(13.5-15.5)\end{array}$ & $\begin{array}{c}14.4 \\
(12.9-15.5)\end{array}$ & $\begin{array}{c}3.9 \\
(3.2-4.5)\end{array}$ & $\begin{array}{c}6.4 \\
(5.9-7.4)\end{array}$ \\
\hline Ranong & $\begin{array}{l}\text { Females } \\
\qquad(\mathrm{N}=4)\end{array}$ & $\begin{array}{c}52.6 \pm 2.53 \\
(49.8-54.8)\end{array}$ & $\begin{array}{c}38.3 \\
(36.9-40.2)\end{array}$ & $\begin{array}{c}14.8 \\
(14.1-16.9)\end{array}$ & $\begin{array}{c}14.8 \\
(13.0-15.8)\end{array}$ & $\begin{array}{c}4.4 \\
(3.9-4.8)\end{array}$ & $\begin{array}{c}6.2 \\
(4.9-6.4)\end{array}$ \\
\hline Locality & Sex & RHW & RIND & RIOD & RUEW & RFLL & R3FDW \\
\hline Phetchaburi and Kanchanaburi & $\begin{array}{l}\text { Males } \\
(\mathrm{N}=7)\end{array}$ & $\begin{array}{c}35.7 \\
(34.0-37.8)\end{array}$ & $\begin{array}{c}11.3 \\
(10.6-12.3)\end{array}$ & $\begin{array}{c}9.3 \\
(8.7-10.1)\end{array}$ & $\begin{array}{c}10.7 \\
(8.5-11.7)\end{array}$ & $\begin{array}{c}67.6 \\
(62.5-70.0)\end{array}$ & $\begin{array}{c}5.9 \\
(4.8-6.8)\end{array}$ \\
\hline Phetchaburi & $\begin{array}{c}\text { Females } \\
(\mathrm{N}=10)\end{array}$ & $\begin{array}{c}34.2 \\
(32.6-35.3)\end{array}$ & $\begin{array}{c}10.6 \\
(9.4-11.9)\end{array}$ & $\begin{array}{c}8.8 \\
(7.9-9.2)\end{array}$ & $\begin{array}{c}9.3 \\
(8.5-10.3)\end{array}$ & $\begin{array}{c}65.6 \\
(62.8-69.8)\end{array}$ & $\begin{array}{c}6.0 \\
(5.2-6.8)\end{array}$ \\
\hline Ranong & $\begin{array}{c}\text { Females } \\
\qquad(\mathrm{N}=4)\end{array}$ & $\begin{array}{c}36.3 \\
(35.5-36.3)\end{array}$ & $\begin{array}{c}10.5 \\
(9.8-10.8)\end{array}$ & $\begin{array}{c}8.7 \\
(7.9-9.0)\end{array}$ & $\begin{array}{c}10.5 \\
(10.0-10.8)\end{array}$ & $\begin{array}{c}64.0 \\
(62.6-69.1)\end{array}$ & $\begin{array}{c}5.7 \\
(5.5-6.6)\end{array}$ \\
\hline Locality & Sex & R4TDW & RHLL & RTL & RFL & R1TL & RIMTL \\
\hline Phetchaburi and Kanchanaburi & $\begin{array}{l}\text { Males } \\
(\mathrm{N}=7)\end{array}$ & $\begin{array}{c}4.5 \\
(3.5-5.0)\end{array}$ & $\begin{array}{c}185.2 \\
(178.6-194.5)\end{array}$ & $\begin{array}{c}60.1 \\
(58.5-63.5)\end{array}$ & $\begin{array}{c}49.0 \\
(46.9-50.2)\end{array}$ & $\begin{array}{c}13.3 \\
(11.9-15.1)\end{array}$ & $\begin{array}{c}4.4 \\
(4.1-4.9)\end{array}$ \\
\hline Phetchaburi & $\begin{array}{c}\text { Females } \\
(\mathrm{N}=10)\end{array}$ & $\begin{array}{c}4.7 \\
(3.9-5.1)\end{array}$ & $\begin{array}{c}189.7 \\
(175.7-199.8)\end{array}$ & $\begin{array}{c}64.5 \\
(57.8-68.1)\end{array}$ & $\begin{array}{c}50.2 \\
(47.8-53.8)\end{array}$ & $\begin{array}{c}14.5 \\
(13.5-16.5)\end{array}$ & $\begin{array}{c}4.7 \\
(4.3-5.4)\end{array}$ \\
\hline Ranong & $\begin{array}{c}\text { Females } \\
(\mathrm{N}=4)\end{array}$ & $\begin{array}{c}4.1 \\
(4.0-4.4)\end{array}$ & $\begin{array}{c}190.6 \\
(183.0-194.1)\end{array}$ & $\begin{array}{c}63.2 \\
(60.2-63.9)\end{array}$ & $\begin{array}{c}50.9 \\
(47.8-51.6)\end{array}$ & $\begin{array}{c}14.3 \\
(13.9-15.0)\end{array}$ & $\begin{array}{c}4.6 \\
(4.4-4.9)\end{array}$ \\
\hline
\end{tabular}

were made mainly following Inger (1985), and staging followed Gosner's (1960) table. For oral apparatus terminology, we followed Altig and McDiarmid (1999).

For comparisons, we examined larvae and metamorphs of $A$. larutensis and $A$. marmoratus (see Appendix 1). We analyzed recorded calls using SoundEdit Vers. 2 and SoundEdit Pro (MacroMind-Paracomp, Inc.) software on a Macintosh computer.

\section{SYSTEMATICS}

\section{Amolops panhai sp. nov.}

(Fig. 1)

Amolops sp.: Chan-ard, 2003, p. 108.

\section{Diagnosis}

A small form of Amolops, males 31-34 mm, females 48-58 $\mathrm{mm}$ in SVL; head narrower than long; tympanum distinct: vomerine teeth grouped in short, oblique patches; first finger subequal to second; disc of first finger smaller than disc of second finger, with circummarginal groove; no wide fringe of skin on third finger; toes fully webbed; outer metatarsal tubercle present; supratympanic fold present; axillary gland present; dorsolateral fold absent or incomplete; horny spines absent on back, side of head and body, and chest; no large tubercles on side of anus; ventral surface of tarsus without glandular fold; male with nuptial pad and paired gular pouches; no white band along the upper jaw extending to shoulder; larvae with the denticle formula of $7(4-7) / 3(1)$.

\section{Etymology}

The specific name is dedicated to Dr. Somsak Panha of Chulalongkorn University, Bangkok, who greatly helped us during our survey in Thailand.

\section{Material examined}

Holotype: CUZM (Chulalongkorn University, Zoological Museum) (A) 5255, an adult male from Pa Lao U, Prachuap
Khiri Khan Province, Thailand (99³1' E, 12॰33' N), collected on 13 December 1995 by M. Matsui.

Paratypes: Five males, CUZM (A) 5256, 5257, KUHE (Kyoto University, Human and Environmental Studies) 20138, 20153, 20198; ten females, CUZM (A) 5258-5262, KUHE 20143, 20163-20165, 20199; fifteen juveniles, CUZM (A) 5263-5269, KUHE 20132, 20133, 20137, 20158, 20161, 20162, 20168, 20169; all paratopotypes with the same collection data as the holotype. One male (KUHE 20022), two juveniles (KUHE 19936, 20021) from Pilok, near Thong Pha Phum, Kanchanaburi Province, Thailand (98`30' E, 14³3' N), collected on 5 December 1995 by M. Matsui, T. Hikida, and J. Nabhitabhata.

Other specimens examined: Six tadpoles (KUHE unnumbered) with the same collection data as the holotype; forty-two juveniles (KUHE 19921-19935, 19945-19949, 19951-19955, 19964-19969, 19972-19980, 20028, 20029), five tadpoles (KUHE unnumbered) from Pilok, Kanchanaburi, collected on 5 December 1995 by M. Matsui; twentyfour juveniles (KUHE 23431, 23432, 23442, 23443, 2347923486, 23493-23504), four females (KUHE 23433, 23434, 23478, 23521), nine tadpoles (KUHE unnumbered) from Punyaban waterfall $\left(98^{\circ} 52^{\prime} \mathrm{E}, 10^{\circ} 06^{\prime} \mathrm{N}, 113 \mathrm{~m}\right.$ a.s.I.), Ranong Province, Thailand, collected on 21 January 1997 by M. Matsui, K. Araya, and T. Hikida.

\section{Description of holotype (measurements in $\mathbf{~ m m}$ )}

Body moderately stocky (Fig. 1), SVL 31.7; head triangular, longer (12.8) than wide (11.6); snout moderately short (5.3), shorter than eye (5.9), rounded at tip in dorsal view, rounded in profile, projecting beyond lower jaw; canthus distinct, constricted; lore slightly oblique, concave; nostril lateral, below canthus, nearer to tip of snout than to eye; internarial distance (3.7) wider than interorbital (3.2); latter slightly narrower than upper eyelid (3.4); eye elevated, 
diameter much larger than eye-nostril; pupil horizontal; tympanum distinct, length (2.9) half of eye diameter and separated from eye by one-third of tympanum diameter (1.0); pineal spot visible, on line connecting anterior corners of orbits; vomerine teeth very weak, in short, oblique groups, three teeth per group, the groups separated from one another by one-fourth the length of one group and from choana by about three times the length of one group, groups on line connecting rear rims of choanae; tongue deeply notched, without papilla; paired subgular vocal sacs form gular pouches at corners of throat; vocal openings just inside comissures of jaws.

Fingers moderately slender, first finger subequal to second, length of first (5.8, measured from distal edge of inner palmar tubercle) subequal to diameter of eye; fourth finger much longer than second; tips of fingers expanded into large discs having circummarginal grooves; disc of second finger (1.7) larger than that of first finger (1.3), discs of third (2.1) and fourth (2.1) fingers largest, two-thirds diameter of tympanum; no webs between fingers; very narrow fringes of skin along third and fourth fingers; subarticular tubercles oval and distinct; distinct inner and two indistinct, elongate outer palmar tubercles; weak supernumerary tubercles between subarticular and palmar tubercles of second and third and at base of fourth fingers.

Hindlimb long (61.0) about three times length of forelimb (22.2); tibia long (19.8), heels overlapping when limbs are held at right angles to body; tibiotarsal articulation of adpressed limb reaching to beyond tip of snout; foot (15.9) shorter than tibia; tips of toes expanded into disks smaller than those of fingers (disk diameter of fourth toe 1.5); webbing between toes full; fringes of skin along medial edge of first toe and along lateral edge of fifth toe; subarticular tubercles oval and distinct; an oval inner metatarsal tubercle, length (1.3) about one-fourth length of first toe (4.5) and smaller than distance between it and subarticular tubercle of first toe (1.6); a small, rounded outer metatarsal tubercle.

Dorsum finely granulated; an incomplete row of tubercles scattered dorsolaterally; side of trunk with scattered tubercles; a weak fold above tympanum from eye; a rictal gland followed by an axillary gland; no dermal ridge on tarsus; throat and chest smooth; abdomen weakly rugose.

Cream-colored asperities forming a nuptial pad covering dorsal and medial surfaces of the first finger from its base to level of subarticular tubercle.

\section{Color in alcohol}

Dorsum dark brown mottled with light olive; lore with indistinct dark band below canthus; upper lip light brown barred with obscure lighter spots; a blackish brown band beginning behind eye reaching inguinal area; limbs marked dorsally with alternating light and dark-brown crossbars; rear of thigh dark brown mottled with irregular light spots; throat very weakly spotted light brown; lower lip indistinctly barred with light brown; abdomen and ventral surfaces of legs cream, weakly scattered with dots of melanophores on legs.

\section{Variation}

Individual variation in size and body proportions is given in Table 1. In adult type series, females are significantly larger $(\bar{x}=53.9 \mathrm{~mm})$ than males $(\bar{x}=32.6 \mathrm{~mm}$; Tukey-Kramer test, $p<0.01)$. Relative lengths of head, eye, tympanum, and interorbital, and relative width of head, are significantly greater in males, while relative length of eye-tympanum is greater in females. Thus, tympanum is smaller than half eye diameter in females. In some males, snout is shorter than eye. In some individuals, nostril is midway between tip of snout and eye. In females, samples from Petchaburi have significantly narrower head and wider fourth toe disk, both relative to SVL, than those from Ranong (Dunn's multiple comparison test, $p<0.05$ ).

Some individuals have bead-like interrupted dorsolateral fold, while the others completely lack it. Dorsum is sometimes scattered with flat granules. Individuals are slightly variable in coloration, with the greatest variation in the extent of the dark spots on the throat and in the development of markings on the back. More than half the females have many dark spots, while most males have no spots on the throat. Samples from Ranong have much clearer dorsal markings than those from Phetchaburi. Juveniles at the time of metamorphosis have SVL of $20.2-21.3 \mathrm{~mm}$.

\section{Eggs}

One female contained various sizes of ova in the ovaries. The diameter of five larger ova ranged from 1.3-1.4 (mean $\pm 2 S E=1.35 \pm 0.05) \mathrm{mm}$. The animal pole and the vegetal pole are cream in color.

\section{Larvae}

Five tadpoles of stages (Gosner, 1960) $25(\mathrm{~N}=2$, TOTL=20.5-34.8 mm, HBL=8.4-12.9 mm), 28 ( $\mathrm{N}=2$, 39.6$43.9 \mathrm{~mm}, 14.1-15.9 \mathrm{~mm}$; Fig. 2), and 31 (43.6 mm, 16.1 $\mathrm{mm}$ ) from the type locality were examined. Head-body oval, broadly rounded at snout, flat below, HBW maximum at level of spiracle $66-71 \%$ (median=67.3\%) of HBL; depth $56-69 \%$ (median=66.1\%) of HBW; eyes dorsolateral, not visible from below, pointing outward, eyeball $11-13 \%$ (median=11.8\%) of HBL; interorbital $182-235 \%$ (median=200.0\%) of eye diameter; eye-snout distance 30-35\% (median=31.5\%) of $\mathrm{HBL}$; nostril open, rim not raised, closer to eye than to tip of snout; internarial $69-90 \%$ (median=78.6\%) of interorbital.

Oral disk ventral, width $60-71 \%$ (median=62.6\%) of HBW; upper lip separated from snout by a groove; lips without papillae except for small papillae in a single row at corners of oral disk, with a second, shorter row of larger papillae antero-medially; denticles $7(4-7) / 3(1)$; beaks heavy, completely black except for outer margins; outer surface smooth; margin finely serrate, about 60 serrae on upper beak; upper beak M-shaped, lower V-shaped; neither beak divided; a large suctorial abdominal disk following oral disk; transverse band of horny tissue absent behind oral disk and indistinct inside lateral and posterior margins of disk; length $53-58 \%$ (median=56.2\%) of HBL; width 75-86\% (median= $81.1 \%$ ) of HBW.

Spiracle sinistral; tube moderately long, length subequal to length of eyeball, pointing upward and backward, free of body wall for half its length; anal tube median, free of tail; tail heavily muscled, dorsal margin strongly convex, deepest before middle, tapering to slightly pointed tip; tail length $144-176 \%$ (median $=171.1 \%$ ) of HBL, maximum depth $25-$ $30 \%$ (median $=24.7 \%$ ) of length; caudal muscle deeper than fins in basal half; dorsal fin origin behind body, fin deeper 


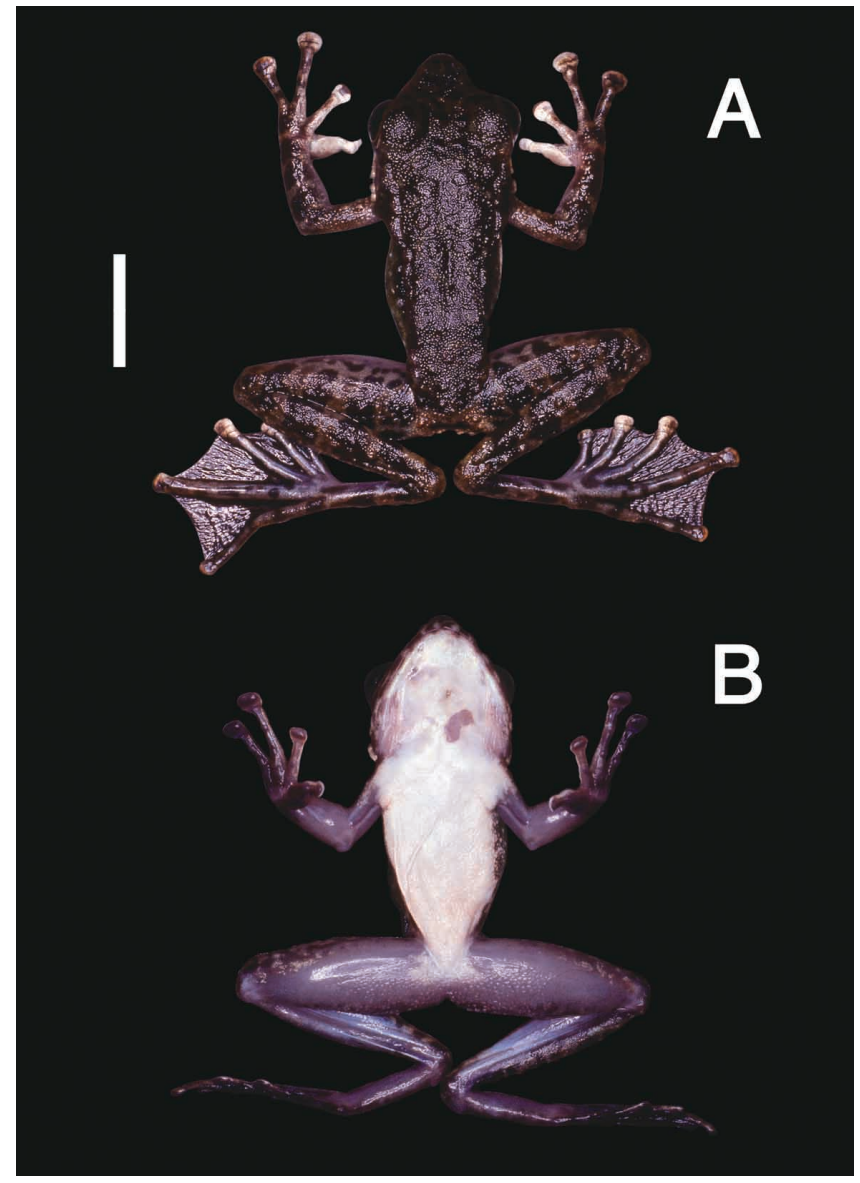

Fig. 1. Male holotype of Amolops panhai [CUZM (A) 5255, $\mathrm{SVL}=31.7 \mathrm{~mm}$. (A) dorsal and (B) ventral views. Scale bar indicates $10 \mathrm{~mm}$.

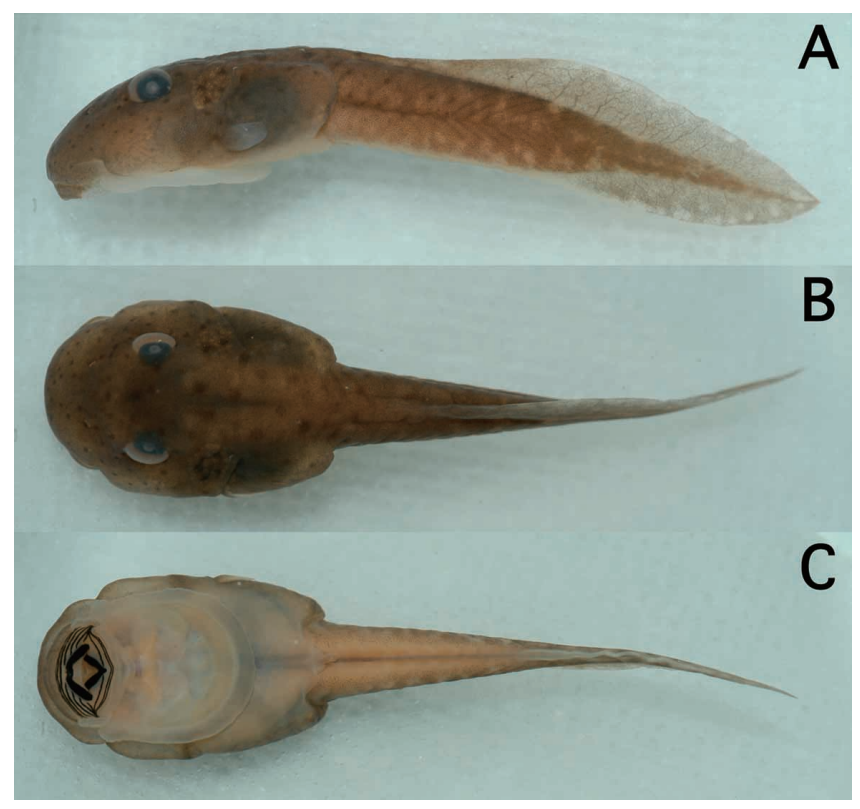

Fig. 2. Larval Amolops panhai (stage 28, total length=39.6 mm). (A) lateral, (B) dorsal, and (C) ventral views. than ventral fin except in final fourth; ventral fin origin at end of proximal third of tail; head-body with two pairs of glandular clusters; an anterior cluster about an eye length behind eye, with about 25 glands; a posterior cluster of about five glands at posterior corner of body; no glands in fins; headbody scattered dorsally with minute protuberances posterior to eye; the area occupied by spinules and their density increasing with stage of development; lateral line pores indistinct, a short row beginning on snout, running below nostril and eye.

Head-body dark brown dorsally and laterally, sometimes scattered with small, black spots dorsally; caudal muscle dark with light mottling; fins with a fine, dark network.

Larvae from Ranong have the body shape similar to those from Prachuap Khiri Khan, but tend to have a shorter abdominal disk [46-53\% (median $=48.7 \%$ ) of $\mathrm{HBL}$ ], and all lack small, dark spots on dorsum. In addition, dark and light marking on the tail is more conspicuous in Ranong samples.

\section{Comparisons}

Two species of Amolops hitherto recorded from Thai-

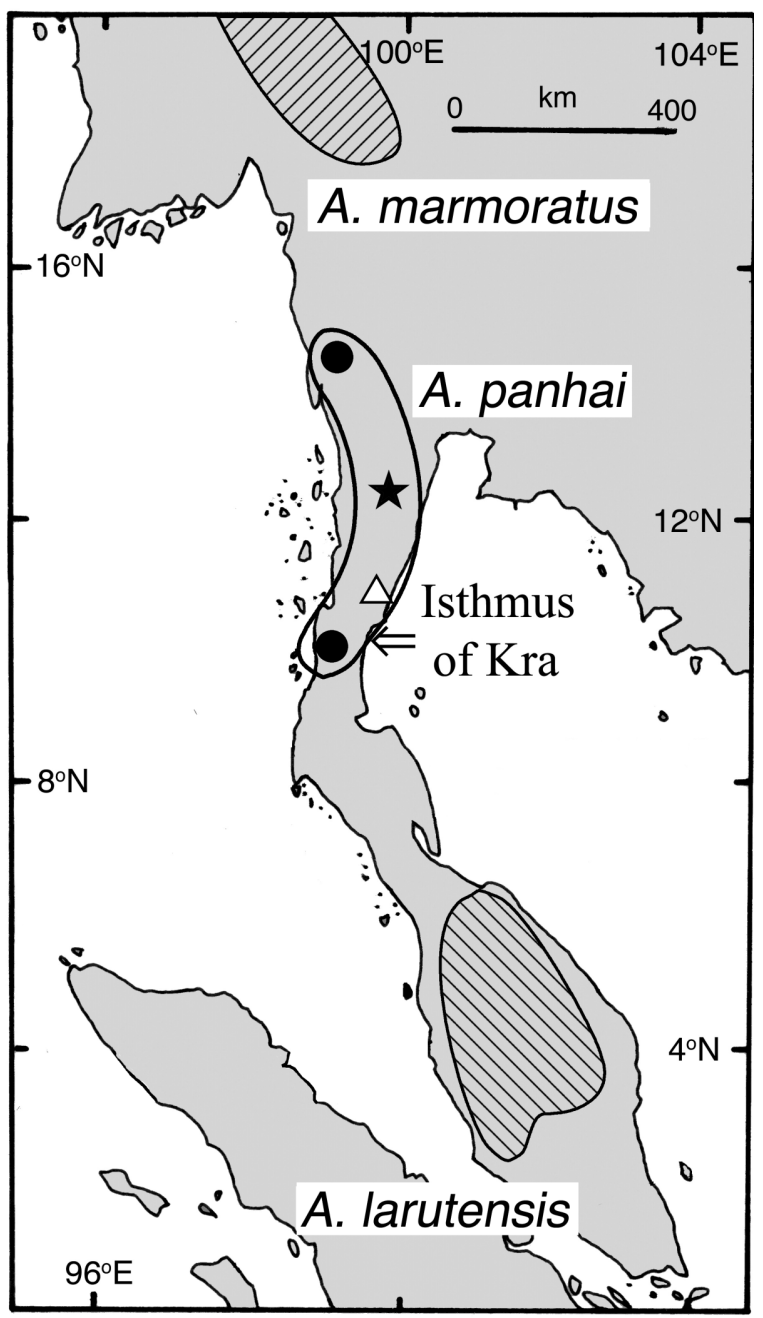

Fig. 3. Map of Southeast Asia showing the Malay Peninsula, western Thailand, and the distribution of three Amolops species. Closed star and circles indicate the type and known localities of $A$. panhai, respectively. Open triangle indicates an old record of $A$. larutensis. 
land, $A$. larutensis and $A$. marmoratus, resemble $A$. panhai in having an outer metatarsal tubercle. However, they differ in some dimensions of body. In both sexes, $A$. panhai is not different from $A$. larutensis in SVL, but is significantly smaller than $A$. marmoratus (Tukey-Kramer test, $p<0.05$ ). In dimensions relative to SVL, $A$. panhai has wider head than $A$. larutensis in male, and has narrower head than $A$. marmoratus and longer tibia than $A$. larutensis in female (Dunn's multiple comparison test, $p<0.05)$. Amolops larutensis is similar to $A$. panhai in having axillary gland, but characteristically has a transverse groove on ventral surface of digital disks, which is absent in $A$. panhai. The larval dental formula of $A$. panhai $[7(4-7) / 3(1)]$ also differs from that of $A$. larutensis $[8(4-8) / 5(1)]$ and $A$. marmoratus $[8(5-8) / 3(1)]$ (our observation).

Amolops panhai differs from the other Amolops species in the following characteristics (data from Andersson, 1938; Fei, 1999; Fei et al., 2005; Inger and Kottelat, 1998; Inger et al., 1999; Liu et al., 2000; Liu and Yang, 2000; Ray, 1992; Yang, 1991): (1) presence of axillary gland (absent in all others including $A$. nepalicus Yang, 1991); (2) presence of vomerine teeth [absent in $A$. daiyunensis (Liu and $\mathrm{Hu}$, 1975), A. hainanensis (Boulenger, 1900), A. hongkongensis (Pope and Romer, 1951), A. torrentis (Smith, 1923), and A. wuyiensis (Liu and $\mathrm{Hu}, 1975)$ ]; (3) presence of distinct, normal tympanum [deeply concave in $A$. gerbillus (Annandale, 1912), indistinct in A. tormotus (Wu, 1977) and A. lifanensis (Liu, 1945)]; (4) presence of outer metatarsal tubercle [absent in $A$. chakrataensis Ray, 1992, A. longimanus (Andersson, 1938), and $A$. spinapectoralis Inger, Orlov, and Darevsky, 1999]; (5) presence of nuptial pad in males (absent in $A$. hainanensis and $A$. torrentis); (6) presence of external vocal sacs in males [absent in $A$. kangtingensis (Liu, 1950), A. loloensis (Liu, 1950), A. mantzorum (David, 1872), A. ricketti (Boulenger, 1899), A. tuberodepressus Liu and Yang, 2000, A. viridimaculatus (Jiang, 1983), A. daiyunensis, $A$. hainanensis, $A$. lifanensis, and $A$. wuyiensis]; (7) head narrow, length greater than width (head wider than long in $A$. jaunsari Ray, 1992); (8) absence of distinct dorsolateral fold [present in $A$. bellulus Liu, Yang, Ferraris, and Matsui, 2000, A. chunganensis (Pope, 1929), A. mengyangensis $\mathrm{Wu}$ and Tian, 1995, A. monticola (Anderson, 1871), A. chakrataensis, A. gerbillus, and A. tormotus]; (9) absence of horny spinules on head, shoulder, or chest [present in $A$. himalayanus (Boulenger, 1888), and $A$. spinapectoralis]; (10) absence of wide fringe of skin on the third finger [present in A. chapaensis (Bourret, 1937), A. formosus (Günther, 1876), A. kaulbacki (Smith, 1940), and $A$. rickett]; (11) absence of a pair of large tubercles on sides of anus [present in A. jinjiangensis Su, Yang, and Li, 1986 and $A$. liangshanensis (Wu and Zhao, 1984)]; and (12) absence of distinct glandular ridge under the tarsus (present in A. cremnobatus Inger and Kottelat, 1998, A. hainanensis, $A$. hongkongensis, and $A$. tormotus).

\section{Calls}

Calls were recorded at Ranong on 21 January 1997 at air and water temperatures of $23.5^{\circ} \mathrm{C}$ and $22.1^{\circ} \mathrm{C}$, respectively. The call consists of a single or a pair of unpulsed short notes each lasting $68-76 \mathrm{msec}$. When the call is paired, the note gap is about $820 \mathrm{msec}$. The call has a marked frequency modulation rising from $5900 \mathrm{hz}$ to 7000 $\mathrm{hz}$, with the dominant being $6500 \mathrm{hz}$.

\section{Range}

Besides the type locality, Pa Lao U, Prachuap Khiri Khan, northern peninsular Thailand, Amolops panhai n. sp. is also known from Pilok, near Thong Pha Phum, Kanchanaburi, western Thailand, and Punyaban waterfall, Ranong, in central peninsular Thailand (Fig. 3). Amolops larutensis recorded from Chumphon (Smith, 1930; Taylor, 1962) is probably actually $A$. panhai (see below).

\section{Natural History}

In Kanchanaburi, a number of juveniles just metamorphosed were collected among stones on riverbeds and on rocks in a wide stream (width $>5 \mathrm{~m}$ ) in early December, but few adults were seen. Tadpoles seen included two groups, those without limb buds, and those just metamorphosing. In Prachuap Khiri Khan, a small number of tadpoles was collected from a stream (width $=5 \mathrm{~m}$ ) in mid December. One of ten females collected had small ovaries with developing ova (see above). In Ranong, adults of $A$. panhai were found along the bank of a stream (width $>5 \mathrm{~m}$ ), perching on rocks at night in late January. Some males were calling, but no amplectant pairs were found. Older tadpoles were collected along with metamorphosing ones. Tadpoles were found in groups, clinging to bare rock in a shallow portion (depth $<20$ $\mathrm{cm}$ ) of the stream, just below a big waterfall; these soon escaped to deeper water when disturbed.

\section{DISCUSSION}

Recent intensive herpetofaunal surveys in Thailand have greatly clarified amphibian diversity in this country. Some species formerly considered wide-ranging have been separated as distinct forms, and some cryptic species have been detected [e.g., the Thai population of Leptobrahium hasselti was described as L. smithi (Matsui et al., 1999); Rana archotaphus was separated from $R$. livida (Inger and Chan-ard, 1997); and Ansonia kraensis was split from $A$. malayana (Matsui et al., 2005)]. The discovery of $A$. panhai is a case similar to the last. Because the adult morphology of $A$. panhai resembles that of $A$. larutensis, old records of the latter species from Chumphon, Isthmus of Kra (Smith, 1930; Taylor, 1962) are likely based on misidentifications of A. panhai.

Amolops panhai has a distributional range between that of $A$. marmoratus (northern Thailand) and $A$. larutensis (southern peninsular Thailand to Malaysia). Based on 1346bp sequences of the mitochondrial 12S and 16S rRNA genes, Matsui et al. (2006) showed a sister relationship of $A$. panhai (as undescribed $A$. sp. from Thailand) with $A$. marmoratus. In contrast, $A$. larutensis formed a clade, though not very strongly, with $A$. cremnobatus from Vietnam (Matsui et al., 2006). These results indicate that an invasion of the A. panhai lineage occurred from north to south along western Thailand.

The present discovery of a new Amolops in Thailand from Kanchanaburi (western region) to Ranong (Isthmus of $\mathrm{Kra}$ ) is significant biogeographically. As already suggested by the geographical separation of species of stream-toads, e.g., Ansonia kraensis from the Isthmus of Kra and $A$. 
malayana from the northern part of Peninsular Malaysia (Matsui et al., 2005), the occurrence of different species between the northern and southern regions of the Malay Peninsula (i.e., A. panhai and $A$. larutensis) contradicts the idea that many amphibian species co-occur in the two regions (Inger, 1999).

Finally, A. panhai differs in dorsal color pattern between northern (Kanchanaburi and Prachuap Khiri Khan) and southern (Ranong) populations. Relevant to this, Matsui et al. (2006) found comparatively high sequence divergence between populations of $A$. panhai from Prachuap Khiri Khan (mistakenly reported as Phetchaburi) and Kanchanaburi $(5.5 \%)$. Further detailed study is required to elucidate the nature of these interpopulation differences.

\section{ACKNOWLEDGMENTS}

We thank S. Panha, T. Hikida, H. Ota, K. Araya, T. Sugahara, M. Toda, and M. Honda for help in the field. The National Research Council of Thailand and the Royal Forest Department of Thailand granted permission for fieldwork in Thailand. We thank S. Tunhikorn for help in obtaining permission, W. Khonsue for providing geographic information, I. Das and K. Nishikawa for providing literature, and A. Tominaga for preparing figures. This study was supported by grants under The Monbusho International Scientific Research Program (Field Research, Nos. 06041066 and 08041144) to M. Matsui.

\section{REFERENCES}

Altig R, McDiarmid W (1999) Body plan: development and morphology. In "Tadpoles: the Biology of Anuran larvae" Ed by W McDiarmid, R Altig, University of Chicago Press, Chicago, pp 24-51

Andersson RC (1938) Batrachians from Burma collected by Dr. R. Malaise, and from Bolivia and Ecuador collected by Dr. C. Hammarlund. Ark Zool 30A: 1-24

Chan-ard T (2003) A Photographic Guide to Amphibians in Thailand. Darnsutha Press, Bangkok

Dubois A (1992) Notes sur la classification des Ranidae (Amphibiens Anoures). Bull Mens Soc Linn Lyon 61: 350-352

Fei $L$ (Ed) (1999) Atlas of Amphibians of China. Henan Science and Technology Press, Zhengzhow

Fei L, Ye CY, Jiang JP, Xi F, Huang YZ (2005) An Illustrated Key to Chinese Amphibians. Sichuan Publishing Group and Sichuan Publishing House of Science and Technology, Chengdu

Frost DR (2004) Amphibian species of the world: an online reference Version 3.0 (22 August, 2004), electronic Database accessible at http://research.amnh.org/herpetology/amphibia/ index.html, American Museum of Natural History, New York
Gosner KL (1960) A simplified table for staging anuran embryos and larvae with notes on identification. Herpetologica 16: 183-190

Inger RF (1966) The systematics and zoogeography of the Amphibia of Borneo. Fieldiana Zool 52: 1-402

Inger RF (1985) Tadpoles of the forested regions of Borneo. Fieldiana Zool New Ser 26: v+1-89

Inger RF (1999) Distribution of amphibians in Southern Asia and adjacent islands. In "Patterns of Distribution of Amphibians: A Global Perspective" Ed by WE Duellman, Johns Hopkins University Press, Baltimore, pp 445-482

Inger RF, Chanard T (1997) A new species of ranid frog from Thailand, with comments on Rana livida (Blyth). Nat Hist Bull Siam Soc 45: 65-70

Inger RF, Kottelat M (1998) A new species of ranid frog from Laos. Raffles Bull Zool 46: 29-34

Inger RF, Orlov N, Darevsky I (1999) Frogs of Vietnam: A report on new collections. Fieldiana Zool New Ser 92: 1-46

Liu WZ, Yang DT (2000) A new species of Amolops (Anura: ranidae) from Yunnan, China, with a discussion of karyological diversity in Amolops. Herpetologica 56: 227-234

Liu WZ, Yang DT, Ferraris C, Matsui M (2000) Amolops bellulus: a new species of stream breeding frog from western Yunnan, China (Anura: Ranidae). Copeia 2000: 536-541

Matsui M (1984) Morphometric variation analyses and revision of the Japanese toads (Genus Bufo, Bufonidae). Contrib Biol Lab Kyoto Univ 26: 209-428

Matsui M, Nabhitabhata J, Panha S (1999) On Leptobrachium from Thailand with a description of a new species (Anura: Pelobatidae). Jpn J Herpetol 18: 19-29

Matsui M, Khonsue W, Nabhitabhata J (2005) A new Ansonia from Isthmus of Kra, Thailand (Amphibia, Anura, Bufonidae). Zool Sci 22: 809-814

Matsui M, Shimada T, Liu WZ, Maryati M, Khonsue W, Orlov N (2006) Phylogenetic relationships of Oriental torrent frogs in the genus Amolops and its allies (Amphibia, Anura, Ranidae). Mol Phylogenet Evol 38: 659-666

Ray P (1992) Two new hill-stream frogs of the genus Amolops Cope (Amphibia: Anura: Ranidae) from Uttar Pradesh (India). Ind J Forest 15: 346-350

Smith M (1930) The Reptilia and Amphibia of the Malay Peninsula from the Isthmus of Kra to Singapore including the adjacent islands. Bull Raffles Mus 3: 1-149

Taylor EH (1962) The amphibian fauna of Thailand. Univ Kansas Sci Bull 43: 265-599

Yang DT (1991) Phylogenetic systematics of the Amolops group of ranid frogs of Southeastern Asia and the Greater Sunda Islands. Fieldiana Zool New Ser 63: 1-42

(Received December 30, 2005 / Accepted January 30, 2006)

Appendix 1. Specimens of $A$. larutenis and A. marmoratus examined for comparisons.

A. marmoratus: KUHE 19030, 19072-19090, 19111, 19112, and KUHE eight unnumbered tadpoles, from Doi Inthanon, Chiang Mai, Thailand; KUHE 19153-19159, 19162, 19217, 19235 from Doi Suthep-pui, Chiang Mai, Thailand; KUHE 19813, 19814, 19828 from Huay Sa Kud and Pang Tong, Mae Hong Son, Thailand.

A. larutenis: KUHE 15437, 15449-15451, 15478-15482, 15497-15502, and KUHE one unnumbered tadpole, from Larut Hills, Malaysia; KUHE 23096, 23097, 23100-23108, 23121, 23136-23139, 23151, 23155, 23160-23166, 23192, 23202-23206, 23213, 23215, 23216, 23218, 23219, 23255, 23256, 23272, and KUHE one unnumbered tadpole, from Hala Bala, Narathiwat, Thailand. 